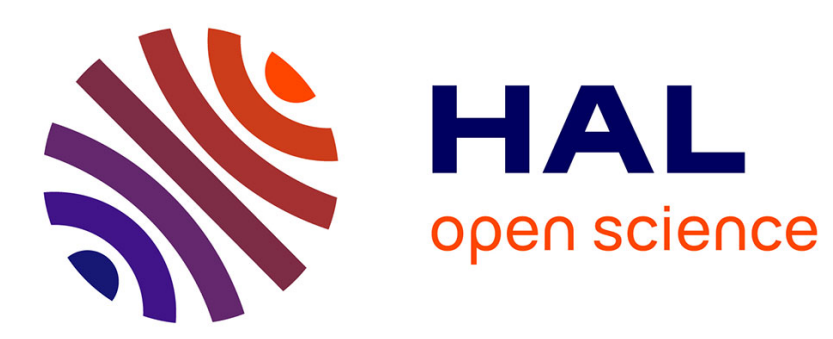

\title{
Modelling in Electromagnetism
}

F. Rioux-Damidau

\section{- To cite this version:}

F. Rioux-Damidau. Modelling in Electromagnetism. Revue de Physique Appliquée, 1990, 25 (7), pp.564-564. 10.1051/rphysap:01990002507056401 . jpa-00246221

\section{HAL Id: jpa-00246221 https://hal.science/jpa-00246221}

Submitted on 1 Jan 1990

HAL is a multi-disciplinary open access archive for the deposit and dissemination of scientific research documents, whether they are published or not. The documents may come from teaching and research institutions in France or abroad, or from public or private research centers.
L'archive ouverte pluridisciplinaire HAL, est destinée au dépôt et à la diffusion de documents scientifiques de niveau recherche, publiés ou non, émanant des établissements d'enseignement et de recherche français ou étrangers, des laboratoires publics ou privés. 


\section{REVUE DE PHYSIQUE APPLIQUÉE}

\section{Modelling in Electromagnetism}

Modelling has become essential for studies and designs in electromagnetism as in many other domains. It generally allows the replacement of the experimentation on a real device, necessarily submitted to many constraints, by computations where the parameters may be modified as much as one likes. If, in a few exceptional cases, modelling may be done analytically, most of the time it requires use of numerical techniques. In the 70's, these were limited to bidimensional systems; in the 80's, they were extended to tridimensional systems that became accessible due to the evolution of computers. This special issue of the Revue de Physique Appliquée publishes articles dedicated to different aspects of modelling. These texts concern, for example, improvements in 3D (mesh eneration studies of different formulations for edd -curren

between electromagnetic and mechanical phenomena or between electric and magnetic equation. Also included are articles dealing with applications of numerical or analytical modelling to study turbogenerators or solid rotor machines, magnet machines or inductive sensors and, finally, the introduction of techniques and codes suited to wave guides (multipoles).

without any claim to be exhaustive, these contributions add to the numerous articles already published by the Revue de Physique Appliquée in the area of modelling in electromagnetism.

F. Rioux-Damidau 